\title{
SERANGAN HAMA DEFOLIATOR PADA BIBIT TANAMAN KEHUTANAN
}

\author{
Sri Utami ${ }^{1}$, Agus Ismanto ${ }^{2)^{*}}$ \\ ${ }^{1}$ Balai Penelitian Kehutanan Palembang \\ Jl. Kol. Burlian KM 6,5 Puntikayu, Palembang \\ ${ }^{2}$ Pusat Penelitian dan Pengembangan Hasil Hutan \\ Jl. Gunung Batu No. 5 Bogor \\ Penulis korespondensi e-mail: aismanto59@gmail.com
}

Diterima : 1 Juni 2016

Disetujui : 1 Oktober 2016

\section{Intisari}

Salah satu upaya untuk menunjang keberhasilan pembangunan hutan tanaman yaitu ketersediaan bibit yang berkualitas (bebas dari serangan hama dan penyakit serta mempunyai kemampuan tumbuh yang baik). Hama defoliator merupakan salah satu permasalahan hama yang sering dijumpai menyerang bibit pada tingkat persemaian. Serangan hama defoliator yang berat mengakibatkan ketidakberhasilan penyediaan bibit. Penelitian dilakukan di persemaian modern di Desa Sukamoro, Kabupaten Banyuasin, Provinsi Sumatera Selatan dari bulan Februari hingga Mei 2013. Tujuan penelitian untuk mengkaji serangan hama pada beberapa jenis bibit kehutanan yaitu bibit Jabon putih (Anthocephalus cadamba), kayu bawang (Dysoxylum molissimum) dan tembesu (Fagraea fragans) masing-masing berumur 1 bulan. Hasil penelitian menunjukkan ditemukan hama defoliator yaitu Arthroschista hilaralis yang menyerang beberapa bibit. Hama A. hilaralis menyerang bibit jabon putih mulai pengamatan minggu ke-2 dengan persentase dan intensitas serangan masing-masing sebesar $40 \%$ dan 30,39\%. Serangan hama tersebut terus meningkat hingga pengamatan pada minggu ke-4 dengan tingkat keparahan $100 \%$. Persentase dan intensitas serangan hama pada bibit kayu bawang masing-masing sebesar 68,72\% dan 40,66 \%. Sedangkan pada bibit Tembesu, persentase dan intensitas serangan hama tergolong rendah masing-masing sebesar 5,83\% dan 3,88\%, yang dijumpai pada pengamatan minggu ke-4. Hal ini menunjukkan bahwa A. hilaralis merupakan salah satu hama yang mempunyai preferensi makan selain pada tanaman inang utamanya yaitu jabon. Oleh karena itu keberadaan hama defoliator $A$. hilaralis pada skala pembibitan perlu diantisipasi. Diperlukan manajemen pengendalian yang tepat dalam mencegah serangan hama ini sehingga kegiatan pembibitan tanaman kehutanan yang dilakukan dalam rangka penyediaan bibit untuk penanaman dalam skala yang lebih luas mengalami keberhasilan.

Kata kunci : A. hilaralis, Jabon, Kayu Bawang, Tembesu

\begin{abstract}
One of the efforts to support the success of forest plantation development is the availability of quality seeds (free from pests and diseases and have the ability to grow good). Defoliator pests is one of the problems frequently encountered pest attack seedlings in the nursery. Defoliator pest attacks will result in the failure of seedlings. The study was conducted at Modern Nursery located in the Sukamoro Village, Banyuasin, South Sumatra Province from February to May 2013. The purpose of the study was to analize the pest which attacks some seedlings e.g. Jabon (Anthocephalus cadamba), kayu bawang (Dysoxylum molissimum) and tembesu (Fagraea fragans) respectively 1 month old. The results showed that Arthroschista hilaralis is defoliator pests that attack several seedlings. A. hilaralis pest attacks Jabon begin observation two week
\end{abstract}


with the percentage and intensity of attack by $40 \%$ and 30,39\% respectively. The pest attacks continue to rise to observations in fourth week with a severity of 100\%. The percentage and intensity of pests on kayu bawang seedling $68,72 \%$ and $40,66 \%$ respectively. On the seedlings tembesu, percentages and intensity of pest attacks 5,83\% and 3,88\% respectively, which is found in the observation of the 4th week. This showed that A. hilaralis is one of the pests that have a preference to eat in addition to its main host plant Jabon. Therefore, the presence of pests defoliator A. hilaralis on a scale nurseries should be anticipated. Management required appropriate controls in preventing these pests so that forestry plant breeding activities are carried out within the framework of the provision of seeds for planting in a broader scale having success.

Keywords : A. hilaralis, Jabon, Kayu Bawang, Tembesu

\section{PENDAHULUAN}

Kehidupan dan pembangunan bangsa Indonesia sangat dipengaruhi oleh keberadaan dan keberlangsungan fungsi hutan. Hal ini dikarenakan hutan memiliki peran penting dan banyak manfaat bagi kehidupan, baik yang bersifat tangible maupun intangible. Selain itu hutan berperan sebagai penyerasi dan penyeimbang lingkungan global, baik dari segi ekologi, ekonomi, maupun sosial. Dari segi ekologi, hutan berfungsi sebagai pelindung terhadap kelangsungan hidup $\square$ ora, fauna dan plasma nutfah serta menjaga kestabilan fungsi hidrologis tanah. Dari segi sosial dan ekonomi, hutan berperan sebagai sumber pencaharian masyarakat setempat dan penghasil devisa negara, baik berupa hasil kayu maupun bukan kayu.

Saat ini Indonesia memiliki 10\% hutan tropis dunia yang masih tersisa. Namun, luas hutan alam ini terus menyusut dengan kecepatan yang sangat mengkhawatirkan. Hutan Indonesia merupakan hutan tropis yang terluas ke-tiga di dunia setelah Brazil dan Republik Demokrasi Kongo. Akan tetapi kondisi hutan di Indonesia saat ini mengalami degradasi dan deforestasi. Laju kerusakan hutan di Indonesia pada tahun 1985-2000 sebesar 1,8 juta ha setiap tahun dan meningkat menjadi 2,84 juta ha setiap tahun pada tahun 1997-2000. Sedangkan dalam periode tahun 2000-2009 (Kementerian Kehutanan 2010), luas hutan Indonesia yang mengalami deforestasi adalah sebesar 15,16 juta ha. Laju deforestasi pada periode tahun 2000-2009 adalah sebesar 1,51 juta ha/tahun, dengan laju deforestasi terbesar terjadi di Kalimantan yaitu sebesar 550.586,39 ha/tahun. Tutupan hutan sebagai salah satu tolok ukur kondisi hutan terus berkurang sejalan dengan intervensi dan eksploitasi yang dilakukan oleh manusia.

Drastisnya penurunan luasan hutan alam di Indonesia dapat mengancam kestabilan kehidupan. Melihat semakin menurunnya jumlah tutupan lahan oleh pohon di wilayah Indonesia, khususnya di pulau Jawa yang saat ini hanya sebesar $4 \%$ dari luas pulau Jawa, maka perlu dilakukan pemulihan hutan. Salah satu cara untuk memulihkan dan meningkatkan kembali luasan hutan adalah melalui penanaman dan pengelolaan hutan tanaman.

Hutan tanaman merupakan jenis pengelolaan hutan yang umum dilakukan saat ini di Pulau Jawa. Pengelolaan hutan tanaman bertujuan untuk memulihkan dan meningkatkan tutupan lahan oleh hutan sekaligus memenuhi kebutuhan manusia akan bahan baku kayu. Kegiatan pembibitan merupakan salah satu kegiatan penting yang sangat menentukan keberhasilan pembangunan hutan tanaman. Bibit yang sehat merupakan aspek penting untuk kesuksesan budidaya tanaman hutan. Dalam kegiatan pembibitan, serangan hama merupakan salah satu permasalahan yang dihadapi dalam budidaya tanaman hutan. Tanaman Jabon putih (Anthocephalus cadamba), Kayu Bawang (Dysoxylum molissimum) dan Tembesu (Fagraea fragans) merupakan jenis-jenis tanaman hutan yang dibudidayakan dalam pembangunan hutan tanaman. Dalam rangka memenuhi permintaan kayu pertukangan dan kayu pulp maka produktivitas yang tinggi dituntut dalam budidaya tanaman tersebut. Oleh karena itu kegiatan monitoring dan pencegahan hama mutlak dilakukan sebagai bahan atau dasar pengambilan kebijakan pengendalian hama untuk 
mensukseskan keberhasilan pembangunan hutan tanaman.

Penelitian bertujuan untuk mengkaji serangan hama pada beberapa jenis bibit kehutanan yaitu bibit jabon putih, kayu bawang dan tembesu masingmasing berumur 1 bulan.

\section{METODE PENELITIAN}

\section{Lokasi dan Waktu Penelitian}

Penelitian dilaksanakan di persemaian modern di Desa Sukamoro, Kabupaten Banyuasin, Provinsi Sumatera Selatan dari bulan Februari hingga Mei 2013.

\section{Bahan dan Alat Penelitian}

Bahan yang digunakan adalah bibit Jabon, Kayu Bawang dan Tembesu berumur 1 bulan masing-masing berjumlah 50 bibit, dan kertas label. Alat yang digunakan yakni hand counter, kotak serangga, ice box, pinset, kamera, dan alat tulis.

\section{Metode Penelitian}

Kegiatan bertujuan untuk memonitor populasi hama pada bibit Jabon, Kayu Bawang dan Tembesu. Kegiatan dilakukan dengan mengamati jenis hama dan tingkat serangan, persentase dan intensitas serangan hama setiap seminggu sekali selama empat minggu.

Identi $\square$ kasi hama dilakukan dengan mengumpulkan telur, ulat, pupa dan atau imago. Identi $\square$ kasi dilakukan di Museum Zoologi, Pusat Penelitian Biologi, Lembaga Ilmu Pengetahuan Indonesia, Bogor.

\section{Penghitungan persentase serangan dan tingkat kerusakan tanaman}

Persentase serangan hama (P) dihitung dengan cara menghitung jumlah bibit yang terserang dalam suatu petak ukur, dibagi jumlah pohon yang terdapat dalam suatu petak ukur di kali $100 \%$.

Jumlah tanaman yang terserang dalam suatu petak ukur

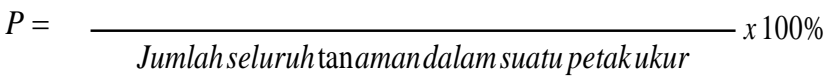

Penghitungan tingkat kerusakan tanaman (I) dilakukan menurut kriteria Unterstenhofer (1963) dalam Djunaedah (1994) dengan sedikit modi $\square$ kasi (Tabel 1 dan Tabel 2). Adapun cara menghitung tingkat kerusakan tanaman dilakukan dengan menggunakan rumus dibawah ini.

$$
I=\frac{\sum\left(n_{i} x v_{j}\right)}{Z x N} \times 100 \%
$$

Keterangan:

I : Tingkat kerusakan tanaman

$\mathrm{n}_{\mathrm{i}}$ : Jumlah pohon yang terserang dengan klasi $\square$ kasi tertentu

$\mathrm{v}_{\mathrm{j}}$ : Nilai untuk klasi $\square$ kasi tertentu

$\mathrm{Z}$ : Nilai tertinggi dalam

klasi $\square$ kasi

$\mathrm{N}$ : Jumlah pohon seluruhnya dalam suatu petak contoh

\section{HASIL DAN PEMBAHASAN}

\section{Jenis Hama}

Berdasarkan hasil penelitian dan identi $\square$ kasi menunjukkan bahwa hama yang menyerang bibit kayu bawang, jabon, dan tembesu yang berumur 1 bulan yaitu Arthroschista hilaralis. Inang utama ulat tersebut adalah daun jabon. Selain menyerang daun jabon, hama tersebut juga menyerang bibit kayu bawang dan tembesu. Hama yang memakan daun sering disebut hama defoliator.

A. hilaralis termasuk ke dalam ordo Lepidoptera, famili Pyralidae. A. hilaralis memiliki ukurantubuh yang kecil dengan sayap depan memanjang dan berbentuk segi tiga dengan sayap belakang yang lebar, serta memiliki palpus labialis yang mencuat kedepan seperti moncong. Borror et al. (1976) menjelaskan bahwa famili Pyralidae merupakan famili terbesar ketiga dalam ordo Lepidoptera.

Telur A. hilaralis berbentuk bulat telur dan akan menetas setelah 2-3 hari diletakkan, dengan ratarata waktu menetas 2,7 hari. Di Bengal Barat (India) periode telur berlangsung selama 3-4 hari (Thapa \& Bhandari 1976). Saat pertama diletakkan telur berwarna putih keruh. Pada hari berikutnya telur akan menjadi kemerahan yang menandakan bahwa telur telah siap menetas. 
Tabel 1. Klasi $\square$ kasi tingkat kerusakan daun yang disebabkan oleh hama

\begin{tabular}{llc}
\hline Tingkat Kerusakan & Tanda Kerusakan yang Terlihat pada Daun & Nilai \\
\hline Sehat & - Kerusakan daun $\leq 5 \%$ & 0 \\
\hline Ringan & - Kerusakan daun antara $5 \%<\mathrm{x} \leq 25 \%$ & 1 \\
\hline Agak berat & - Kerusakan daun antara $25 \%<\mathrm{x} \leq 50 \%$ & 2 \\
\hline Berat & - Kerusakan daun antara $50 \%<\mathrm{x} \leq 75 \%$ & 3 \\
\hline
\end{tabular}

Tabel 2. Klasi $\square$ kasi tingkat kerusakan batang yang disebabkan oleh hama

\begin{tabular}{llc}
\hline Tingkat Kerusakan & Tanda Kerusakan Yang Terlihat pada Tanaman & Nilai \\
\hline Sehat & - Batang rusak $0 \%$ & 0 \\
\hline Ringan & - Batang rusak antara $1 \%-20 \%$ & 1 \\
\hline Agak berat & - Batang rusak antara $20,1 \%-40 \%$ & 2 \\
\hline Berat & - Batang rusak antara $40,1 \%-60 \%$ & 3 \\
\hline Sangat berat & - Batang rusak antara $60,1 \%-80 \%$ & 4 \\
\hline Gagal & - Batang rusak di atas $80 \%$ & 5 \\
& - Pohon tumbang/patah/mati & \\
\hline
\end{tabular}

Larva A. hilaralis memiliki tubuh berbentuk silindris dengan tiga pasang tungkai sejati pada bagian thoraks dan terdapat 4 pasang tungkai semu pada ruas ketiga hingga keenam abdomen (Gambar 1). Stadium larva merupakan fase perkembangan terlama dalam siklus hidup A. hilaralis. Rata-rata waktu yang diperlukan A. hilaralis pada stadium ini adalah 12,6 hari dengan kisaran waktu 11-15 hari. Di Sabah (Malaysia) rata-rata waktu yang diperlukan pada stadium larva 12-16 hari sedang di West Bengal (India) 13-15 hari (Thapa 1970; Thapa \& Bhandari 1976).

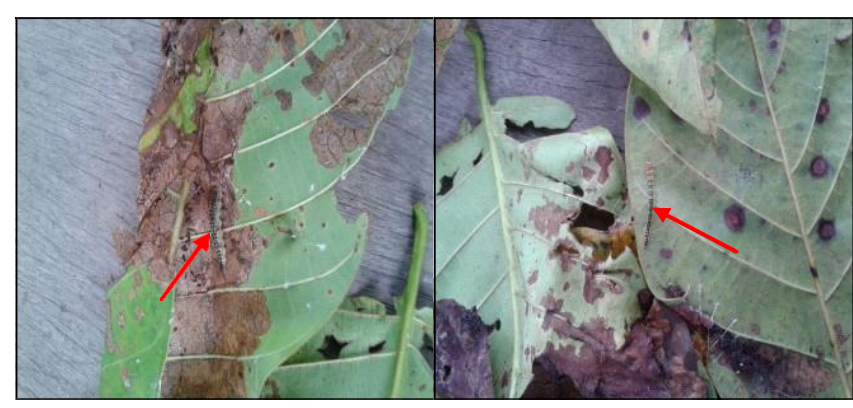

Gambar 1. Larva A. hilaralis (tanda panah)

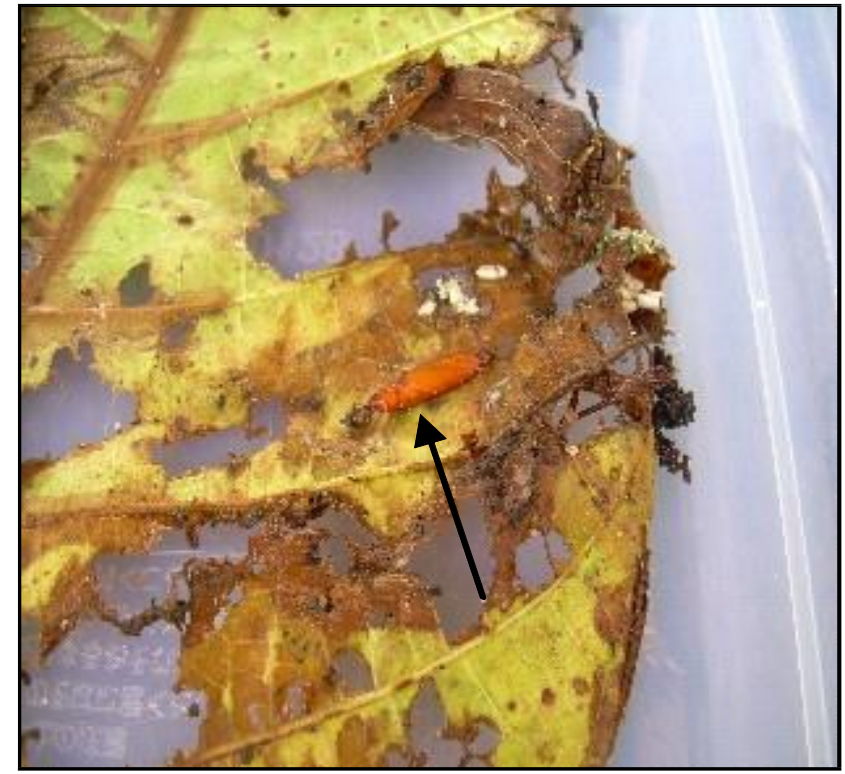

Gambar 2. Pupa A. hilaralis (tanda panah)

Pupa A. hilaralis termasuk ke dalam tipe obtekta (Gambar 2). Bagian bakal antena, bakal mulut, bakal sayap dan bakal tungkai melekat pada tubuh dan tidak dapat dipisahkan. Pupa A. hilaralis berwarna 
coklat muda dengan rata-rata panjang $14,50 \mathrm{~mm}$ dan lebar 3,01 mm. Perbedaan pupa jantan dan betina ditandai oleh adanya tonjolan pada sternum abdomen ruas terakhir pada pupa betina, sedangkan pada pupa jantan tidak terdapat tonjolan. Stadium pupa rata-rata berlangsung salama 6,9 hari dengan kisran waktu 6-8 hari. Di West Bengal (India) periode pupa berlangsung selama 5-7 hari (Thapa \& Bhandari 1976).

Imago A. hilaralis berwarna hijau kebiruan dengan warna kuning oranye di sepanjang costa sayap (Gambar 3). Imago jantan dan betina memiliki ukuran tubuh yang tidak berbeda nyata. Lama hidup imago jantan lebih singkat dari imago betina. Rata-rata lama hidup imago jantan 4,0 hari, sedangkan imago betina 6,9 hari. Imago jantan dan betina dapat dibedakan dari bentuk ujung abdomennya. Pada imago jantan ujung abdomen ditumbuhi rambut-rambut yang lebat dan berwarna hitam, sedang pada imago betina tidak terdapat rambut-rambut pada ujung abdomen.

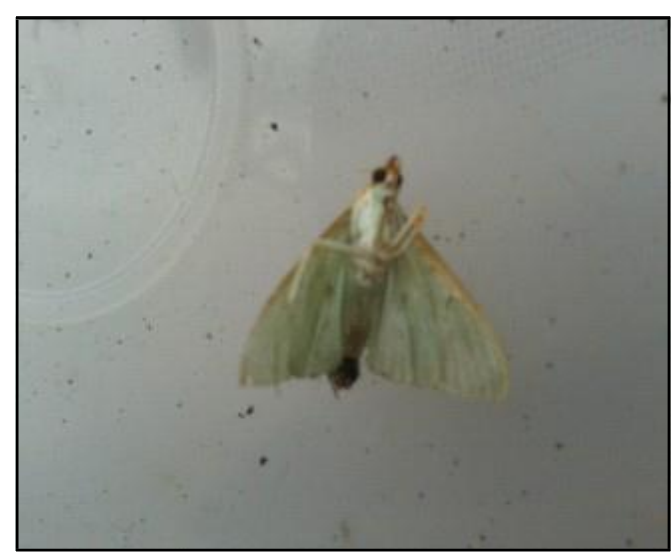

Gambar 3. Imago A. hilaralis

\section{Gejala Serangan}

Gejala serangan ulat $A$. hilaralis pada bibit kayu bawang, jabon maupun tembesu yaitu adanya lubang-lubang bekas gigitan ulat. Serangan ulat defoliator biasanya dimulai dari pucuk daun kemudian berlanjut pada daun-daun di bawahnya (Gambar 4). Ulat akan menggulung daun ke arah dalam. Serangan yang berat dapat mengakibatkan daun kering, gundul dan rontok. Serangan paling berat pada bibit jabon karena memang tanaman inang utama. Kemudian serangan yang tergolong sedang pada bibit kayu bawang, dan tingkat serangan rendah pada bibit tembesu. Diduga kondisi $\square$ sik tanaman seperti kehalusan permukaan

daun (tidak banyak terdapat duri atau trikoma pada daun) mempengaruhi preferensi hama tersebut terhadap tanaman inangnya. Senyawa metabolit sekunder yang terkandung dalam masing-masing bibit tanaman kemungkinan memberikan pengaruh perilaku ulat dalam menemukan inangnya.

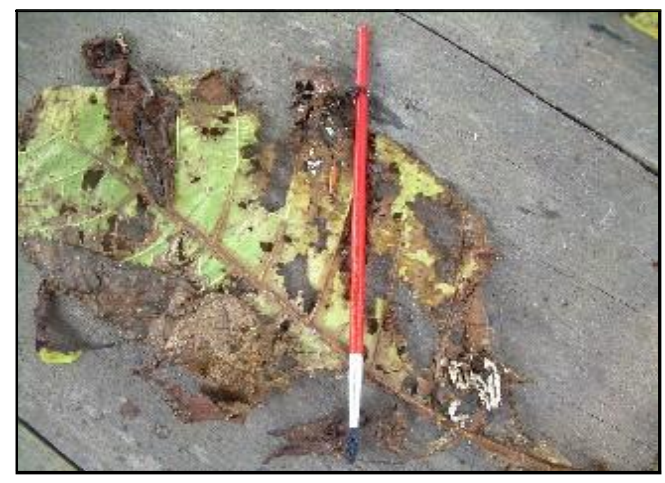

Gambar 4. Gejala serangan ulat A. hilaralis

\section{Tingkat Serangan Hama}

Pada minggu pertama tidak dijumpai serangan hama $A$. hilaralis pada bibit kayu bawang, jabon maupun tembesu. Serangan hama A. hilaralis baru ditemukan pada minggu ke-dua. Hanya bibit jabon yang terserang ulat $A$. hilaralis dengan persentase dan intensitas serangan masing-masing sebesar $45 \%$ dan 30,39\% sebagaimana tersaji pada Gambar 5 dan 6. Jabon merupakan tanaman inang utama ulat $A$. hilaralis. Pada pengamatan minggu ketiga ditemukan bahwa ulat $A$. hilaralis tidak hanya menyerang bibit jabon tetapi juga menyerang bibit kayu bawang sedangkan bibit tembesu belum terserang hama ulat. Persentase dan intensitas serangan hama ulat pada bibit jabon dan kayu bawang berturut-turut $100 \%$ dan $85 \% ; 68,72 \%$ dan $40,66 \%$.

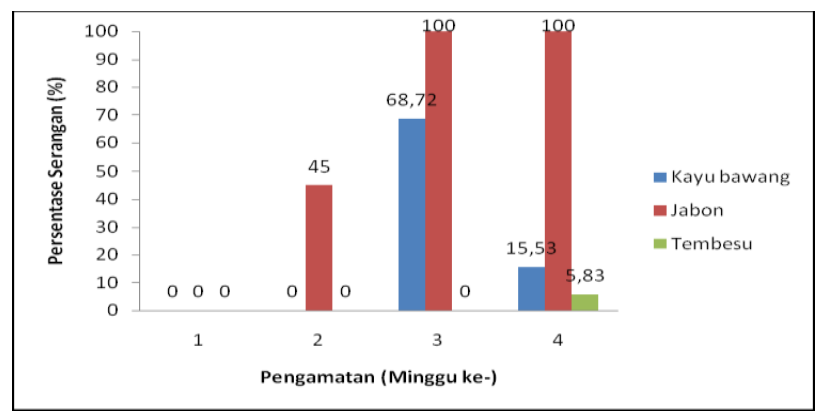

Gambar 5. Persentase serangan ulat A. hilaralis pada bibit jabon, kayu bawang dan tembesu selama empat kali pengamatan 


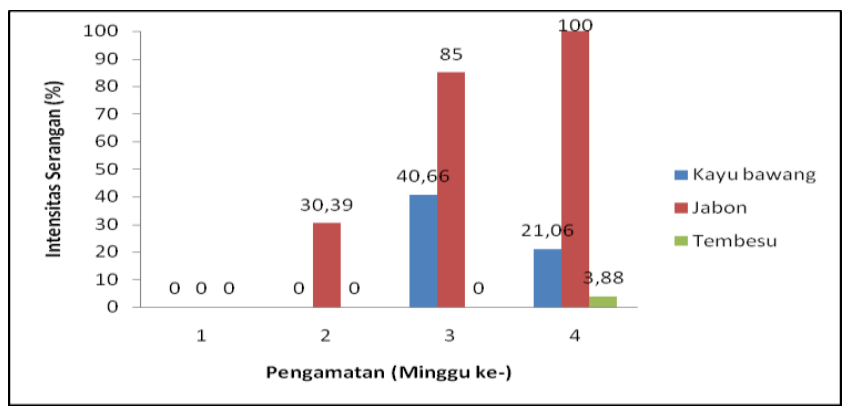

Gambar 6. Intensitas serangan ulat A. hilaralis pada bibit jabon, kayu bawang dan tembesu selama empat kali pengamatan

Pengamatan minggu ke-empat dimana pada bibit jabon sudah dijumpai serangan yang parah dan berat di mana hampir semua daun sudah gundul dimakan ulat dengan persentase dan intensitas serangan sebesar $100 \%$, hama ulat mempunyai preferensi ke tanaman lain selain tanaman Kayu Bawang yaitu bibit Tembesu. Besarnya persentase dan intensitas serangan ulat $A$. hilaralis pada bibit kayu bawang yaitu sebesar $15,53 \%$ dan $21,06 \%$, sedangkan pada bibit Tembesu masing-masing sebesar 5,83\% dan 3,88\% sebagaimana tersaji pada Gambar 5 dan Gambar 6.

Tanaman memiliki peran yang penting dalam membentuk perilaku dan evaluasi serangga herbivora (Ehrlich \& Raven 1967). Serangga memperoleh nutrisi dan tanaman sebagai makanannya, dan kedua organisme yang berbeda ini dihubungkan oleh senyawa kimia yang disebut allelokemik.

Terdapat beberapa faktor yang mempengaruhi interaksi antara tanaman dengan serangga di antaranya yaitu pertahanan tanaman yang meliputi struktur $\square$ sik atau tekstur tanaman dan bahan kimia tanaman. Faktor $\square$ sik seperti morfologi, anatomi dan warna tumbuhan mempengaruhi ketahanan suatu tanaman terhadap serangga. Sodiq (2009) melaporkan bahwa eksudasi yang dikeluarkan oleh trikoma pada tanaman Solanaceae menghalangi gerakan kutu-kutu daun seperti Myzus persicae, Macrosiphun euphorbiadae dan Tetranichus cinnabarium. Duri halus yang terdapat pada bagian bawah daun atau pada tulang daun telah dilaporkan dijumpai pada tanaman yang kurang peka terhadap penggerek pucuk tebu Scirpophoga nivell

Peran kimia tumbuhan sangat besar kaitannya dengan interaksi yang terjadi antara serangga dengan tumbuhan disamping peranan $\square$ sik atau morfologi tumbuhan. Proses-proses seperti penemuan inang oleh serangga baik untuk aktivitas makan maupun aktivitas peneluran akan melibatkan senyawa kimia tumbuhan. Senyawa-senyawa yang berperan dalam mempengaruhi tingkah laku serangga digolongkan berdasarkan pengaruhnya pada respon sensori yaitu 1) Senyawa-senyawa yang memberikan respon positif seperti senyawasenyawa yang bersifat atraktan atau penarik, dan

2) Senyawa yang memberikan respon negative seperti senyawa-senyawa yang bersifat repelen atau penolak (Dadang dan Prijono 2008). Senyawa kimia tumbuhan yang mempengaruhi interaksi antara tanaman dengan serangga meliputi senyawa metabolit primer dan senyawa metabolit sekunder. Pada tumbuhan metabolit primer adalah bagian yang lebih besar dari biomassa tumbuhan itu sendiri. Beberapa metabolit primer merupakan senyawa esensial yang terlibat dalam proses-proses $\square$ siologi tumbuhan seperti karbohidrat, protein, lemak dan lain sebagainya yang juga bersifat esensial bagi serangga dan herbivora lainnya.

Kartosuwondo dan Sunjaya (1990) melaporkan bahwa preferensi dan perkembangan serangga herbivor terhadap berbagai jenis tumbuhan inang bervariasi bergantung pada kuantitas maupun kualitas senyawa kimia primer dan sekunder pada tumbuhan inang. Senyawa primer mengandung nutrisi, sedangkan senyawa sekunder bekerja sebagai perangsang makan dan tidak memiliki nilai nutrisi bagi serangga (Fraenkel 1959).

Preferensi dan non preferensi menunjukkan hubungan antara sifat-sifat tanaman dan tanggap serangga, yang menyebabkan tanaman terpilih atau tidak terpilih oleh serangga untuk meletakkan telur, makan atau berlindung, atau kombinasi ketiganya (Watson el al. 1988). Proses makan serangga mengikuti urutan perilaku sebagai berikut, yaitu penemuan dan pengenalan inang, kegiatan makan awal (menggigit, menusuk), kegiatan makan dan berhenti makan (Beck 1965), sedang menurut 
Beck (1965) dan Ramaswamy (1988) dalam proses peletakan telur serangga mengikuti urutan perilaku sebagai berikut : gerakan menuju ke tanaman, penemuan dan pengenalan inang, dan peletakan telur. Tanaman inang yang sesuai mempunyai stimuli untuk semua tahapan itu. Tanaman yang tahan adalah tanaman yang tidak dapat menyediakan stimuli untuk setiap proses makan. Hanya tanaman yang memiliki stimuli pada bagian tertentu dari tahapan di atas yang menyebabkan proses makan terhambat (Kogan 1982).

Sastrosiswodjo dan Setiowati (1991) melaporkan bahwa alat indra serangga dapat menemukan tanaman inang yang disukai. Menurut Kogan (1982) proses seleksi inang oleh serangga $\square$ tofag merupakan satu rangkaian dari kejadian rangsangan dari tanaman dan respon serangga. Ada lima tahapan yang harus dilalui serangga dalam pemilihan inang yaitu : 1) Penemuan habitat inang, populasi imago biasanya menyebar melalui beberapa mekanisme yang mencakup fototaksis, anemotaksis dan geotaksis, 2) Penemuan inang; dalam hal ini indra penciuman dan mata mempunyai peran yang penting, beberapa tanaman mengeluarkan bau yang menarik serangga juga warna tanaman mempunyai peran penting, 3) Pengenalan inang, indra peraba dan perasa membantu serangga untuk mengenali tanaman inangnya, beberapa serangga mencicipi tanaman sebelum meletakkan telur, 4) Penerimaan inang; setelah mencicipi tanaman dan dirasa cocok, maka serangga meneruskan makannya, dan 5) Kesesuaian inang; nilai nutrisi tanaman dan ada tidaknya senyawa yang bersifat toksik akan menentukan pertumbuhan dan perkembangan serangga, juga lama hidup dan fekunditas imago. Dalam pemilihan inang ini factor $\square$ sik dan kimia tanaman juga memegang peranan yang penting.

Serangga tertarik atau tidak kepada tanaman karena adanya zat kimia atau morfologi tanaman inang. Hal ini menimbulkan respon pada serangga yang merupakan seleksi dalam menggunakan bagian tertentu dari tanaman untuk dimakan, meletakkan telur, tempat berlindung atau kombinasi ketiganya. Sifat morfologi atau struktur tanaman dapat mengurangi tingkat kesukaan serangga untuk memilih tanaman tersebut sebagai inangnya. Adanya rambut yang halus atau trichoma akan menyulitkan serangga untuk meletakkan telur.

\section{KESIMPULAN}

1. Jenis serangan hama yang menyerang bibit Kayu Bawang, Jabon dan Tembesu yaitu Arthroschista hilaralis (Lepidoptera : Pyralidae).

2. Ulat A. hilaralis mempunyai preferensi inang terhadap ketiga jenis bibit tanaman hutan.

3. Serangan ulat A. hilaralis paling berat pada bibit jabon, kemudian diikuti bibit kayu bawang dan serangan paling rendah pada bibit tembesu.

\section{DAFTAR PUSTAKA}

Beck, S.D. 1965. Resistance of Plants to Insects. Ann. Rev. Entomol. 10:207-224.

Borror, D.J., Delong, D.M., and Triplehorn C.A. 1976. An Introduction to the Study of Insects. New York (US): Holt, Rinehart and Winston.

Dadang dan Prijono, D. 2008. Insektisida Nabati: Prinsip, Pemanfaatan dan Pengembangan. Departemen Proteksi Tanaman. Fakultas Pertanian. Institut Pertanian Bogor. Bogor.

Djunaedah, S. 1994. Pengaruh perubahan lingkungan bio $\square$ sik dari hutan alam ke hutan tanaman terhadap kelimpahan keragaman famili serangga dan derajat kerusakan hama pada tegakan jenis Eucalyptus uerophylla, E. deglupta dan E. pellita [Tesis]. Bogor: Institut Pertanian Bogor.

Ehrlich, P.R., Raven, C.H. 1965. Butter $\square$ ies and Plants: a Study in Coevolution. Evolution 18:586-608.

Kementerian Kehutanan. 2010. Statistik Kehutanan Indonesia. Kementerian Kehutanan. Jakarta.

Kogan, M. 1982. Plant Resistance in Pest Management dalam R.L. Metcalf and W. H. Lukman (eds.) Introduction to Insect Pest Management. John Wiley and Sons, New York, pp. 93-94.

Ramaswamy, S.B. 1988. Host Finding by Moth: Sensory Modalities and Behaviours. J. Insect Physiol; 34(3):235-249. 
Sastrosiswodjo, S. dan Setiowati, W. 1991. Daya Racun Insektisida Mikroba (Bacillus thuringiensis) dan Penghambatan Pembentukan Kitin terhadap Larva Crocidolomia binotalis Zell. Bull. Penel. Hort; XXI(1):17-19.

Thapa R.S. 1970. Bionomic and Control of Laran Defoliator, Margaronia hilaralis Walk. (Lepidoptera: Pyralidae). The Malayan Forest; 33(1):55-62.
Thapa R.S, and Bhandari R.S. 1976. Biology, Ecology and Control of Kadam Defoliator, Arthroschista hilaralis Walk. (Lepidoptera:Pyralidae) in plantation in West Bengal. Indian For; 102(6):333-401.

Watson, T.F, Moore, L, and Ware, G.W. 1988. Practical Insect Pest Management. A SelfInstruction Manual. Host-Plant Resistance.W.H. Freeman and Company, San Fransisco 